\title{
Invaders in hot water: a simple decontamination method to prevent the accidental spread of aquatic invasive non-native species
}

\author{
Lucy G. Anderson • Alison M. Dunn • \\ Paula J. Rosewarne $\cdot$ Paul D. Stebbing
}

Received: 28 August 2014 / Accepted: 6 March 2015/Published online: 26 March 2015

(C) The Author(s) 2015. This article is published with open access at Springerlink.com

\begin{abstract}
Watersports equipment can act as a vector for the introduction and spread of invasive non native species (INNS) in freshwater environments. To support advice given to recreational water users under the UK Government's Check Clean Dry biosecurity campaign and ensure its effectiveness at killing a range of aquatic INNS, we conducted a survival experiment on seven INNS which pose a high risk to UK freshwaters. The efficacy of exposure to hot water $\left(45^{\circ} \mathrm{C}, 15 \mathrm{~min}\right.$ ) was tested as a method by which waters users could 'clean' their equipment and was compared to drying and a control group (no treatment). Hot water had caused $99 \%$ mortality across all species $1 \mathrm{~h}$ after treatment and was more effective than drying at all time points $\left(1 \mathrm{~h}: \chi^{2}=117.24\right.$, $p<0.001 ; 1$ day $\chi^{2}=95.68, p<0.001 ; 8$ days $\chi^{2}=$ 12.16, $p<0.001$ and 16 days $\chi^{2}=7.58, p<0.001$ ). Drying caused significantly higher mortality than the control (no action) from day $4\left(\chi^{2}=8.49, p<0.01\right)$
\end{abstract}

Electronic supplementary material The online version of this article (doi:10.1007/s10530-015-0875-6) contains supplementary material, which is available to authorized users.

L. G. Anderson $(\bowtie) \cdot$ A. M. Dunn · P. J. Rosewarne School of Biology, University of Leeds, Leeds LS2 9JT, UK

e-mail: bslga@leeds.ac.uk

P. D. Stebbing

Centre for Environment, Fisheries and Aquaculture

Science (Cefas), Barrack Road, The Nothe, Weymouth,

Dorset DT4 8UB, UK onwards. In the absence of hot water or drying, 6/7 of these species survived for 16 days, highlighting the importance of good biosecurity practice to reduce the risk of accidental spread. In an additional experiment the minimum lethal temperature and exposure time in hot water to cause $100 \%$ mortality in American signal crayfish (Pacifastacus leniusculus), was determined to be 5 min at $40{ }^{\circ} \mathrm{C}$. Hot water provides a simple, rapid and effective method to clean equipment. We recommend that it is advocated in future biosecurity awareness campaigns.

Keywords Angling equipment · Biosecurity · Invasive species management $\cdot$ Watersports equipment

\section{Introduction}

Invasive non native species (INNS) can have profound impacts on the marine, terrestrial and freshwater ecosystems they invade by replacing native species, altering community structure and introducing novel diseases (Mack et al. 2000). Freshwater systems are particularly vulnerable to the introduction of INNS due to their exposure to multiple transport pathways along which new species can be either accidentally or intentionally introduced. Moreover, the ecological resilience of freshwater systems is already reduced by pollution, agricultural run-off and altered hydrology (Strayer 2010), increasing the likelihood that non- 
native species will successfully invade (Dudgeon et al. 2006).

Fishing, boating and leisure activities are collectively responsible for almost $40 \%$ of aquatic species introductions into Europe (Gallardo and Aldridge 2013). These pathways commonly include the release of boat ballast water and the stocking and subsequent escape of non-native fish or crustaceans introduced for aquaculture or sport. However, they also include the accidental transfer of invasive plants and invertebrate species "hitchhiking" on personal equipment such as angling nets, bait buckets, wet suits and waders used during recreational activities (Ludwig and Leitch 1996; Buchan and Padilla 1999; Johnson et al. 2001; Gates et al. 2008; Stebbing et al. 2011; Stasko et al. 2012; Bacela-Spychalska et al. 2013). Such accidental transfer is thought to have been responsible for new introductions, as well as facilitating the secondary spread of species once introduced (Johnson et al. 2001; Bothwell et al. 2009; Kilian et al. 2012).

Freshwater ecosystems in the UK contain seven of the UK Environment Agency's 10 'most wanted' INNS (Environment Agency 2011) and are thought to be threatened by a further 11 (Gallardo and Aldridge 2013). Many of these aquatic invasive species can survive for several days in damp environments. For example, zebra mussels can survive outside water for at least 5 days (Ricciardi et al. 1995) and killer shrimp (Dikerogammarus villosus) for at least 15 days (Fielding 2011). As $64 \%$ of anglers visit more than one catchment within a fortnight (Anderson et al. 2014), it is likely that many aquatic INNS could survive the journey from an invaded catchment to an uninvaded catchment on damp equipment if effective biosecurity measures are not in place.

Once established, the eradication of these species is virtually impossible (Mack et al. 2000; Kolar and Lodge 2001; Briski et al. 2012) and control measures costly (Oreska and Aldridge 2010). Preventing their initial introduction and spread through effective biosecurity is therefore considered a far more effective management strategy (Vander Zanden et al. 2010; Caplat and Coutts 2011; Briski et al. 2012). The Check Clean Dry campaign was launched in the UK by the Government's Department of Environment, Food and Rural Affairs (Defra) in 2010. The objective of the campaign is to raise awareness of good biosecurity practices among recreational water users to prevent the introduction and spread of aquatic INNS. The campaign provides broad guidance for best-practice:

Check your equipment and clothing for live organisms-particularly in areas that are damp or hard to inspect. Clean and wash all equipment thoroughly. If you do come across any organisms, leave them at the water body where you found them. Dry all equipment and clothingsome species can survive for many days in damp conditions. Make sure you don't transfer water elsewhere." (Defra 2013)

Specific advice about the most effective method by which to clean equipment is required.

Thermal control is considered to be one of the most efficient, environmentally sound and cost effective methods by which to prevent the accidental spread of aquatic INNS (O’Neill and MacNeill 1991; Beyer et al. 2010; Stebbing et al. 2011; Perepelizin and Boltovskoy 2011). Preliminary research conducted by the Centre for Environment, Fisheries and Aquaculture Science (Cefas) indicated that submersion in hot water at $45^{\circ} \mathrm{C}$ was sufficient to cause $100 \%$ mortality in D. villosus within $15 \mathrm{~min}$ (Stebbing et al. 2011). This advice has since been incorporated within local biosecurity awareness programmes (e.g. (Broads Authority 2013).

Hot water at this temperature meets the essential criteria for an effective cleaning treatment: it is accessible, economical, requires no specific training or protective equipment to use and has no impact on the environment when disposed (potentially in large volumes) (Kilroy et al. 2006). However, the recommended cleaning treatment needs to be effective at killing a wide range of aquatic INNS in addition to D. villosus as it is unrealistic to expect water users to use multiple treatments for different species, or to know which invasive species are present in different waterways.

Previous studies indicate that hot water can also cause $100 \%$ mortality in zebra mussels (D. polymorpha), quagga mussels (Dreissena rostriformis bugensis) and the planktonic lifestage of spiny water fleas (Bythotrephes longimanus) (Beyer et al. 2010) as well as the invasive diatom didymo (Didymo germinata) (Kilroy et al. 2006) suggesting potential efficacy of this treatment across a range of taxonomic groups. Whether the $45{ }^{\circ} \mathrm{C} / 15 \mathrm{~min}$ protocol is effective across multiple INNS, including plants, remains to be tested however. 
The study had three aims: (1) to test whether the cleaning and drying components of the Check Clean Dry protocol were effective at killing a range of aquatic INNS should they become tangled in anglers keep nets; (2) to evaluate whether hot water at $45{ }^{\circ} \mathrm{C}$ is an effective method for killing a range of high impact aquatic INNS; and (3) to conduct a pilot experiment to test whether hot water could be a feasible biosecurity treatment for larger INNS such as American signal crayfish.

\section{Materials and methods}

Survival experiments were conducted during October/ November 2013 and February/March 2014 to evaluate the effectiveness of drying and hot water as treatments for decontaminating angling nets. Seven aquatic INNS representing a range of taxa and all currently present in the UK were used: zebra mussels (Dreissena polymorpha), killer shrimp (D. villosus), bloody-red mysid (Hemimysis anomala), floating pennywort (Hydrocotyle ranunculoides), curly water-thyme (Lagarosiphon major), New Zealand Pigmyweed (Crassula helmsii), and parrot's feather (Myriophyllum aquaticum). Species were selected due to their classification as high impact invaders by the UK Technical Advisory Group for the EU Water Framework Directive.

A second experiment to test the effect of hot water temperature and duration of exposure on the survival of signal crayfish (Pacifastacus leniusculus) was conducted during March 2014. Adult crayfish were used as a proxy for juvenile crayfish (which may be difficult for anglers to detect) because juveniles were not accessible at the time of year when the experiment was undertaken. It was also reasoned that a treatment that is effective in killing adults is likely to also be effective for juveniles due limited ontogenetic changes in body morphology between juvenile and adult crayfish life stages (Holdich 2001).

The animals and plants were collected from various sites across the UK using hand searching (zebra mussels, killer shrimp, bloody-red mysid, signal crayfish) or from UK retailers of aquatic pond plants where it was unfeasible to collect wild specimens (Lagarosiphon major, parrot's feather, New Zealand pigmyweed, curly water thyme). Once collected, plants/animals were stored in separate tanks of dechlorinated, aerated tap water at constant temperature $\left(14 \pm 1{ }^{\circ} \mathrm{C}\right.$, light: dark cycle $12: 12 \mathrm{~h}$ ) for at least $48 \mathrm{~h}$ before the experiment to enable acclimation to laboratory conditions and recovery from collection or transport-induced stress. The temperature conditions were chosen to reflect the conditions in a garage or shed, the conditions in which most anglers store their equipment (Anderson et al. 2014).

\section{Check Clean Dry experiment}

At the start of the experiment, plants were removed from the tank and cut into fragments of approximately $60 \mathrm{~mm}$ to simulate a fragment of plant that may become broken off and tangled up in an angling net. As the plant species were all vegetative reproducers, care was taken to include the reproductive part of the plant in each fragment. A FluorPen (FP 100, Photon Systems Instruments, Czech Republic) was used to determine the equivalent variable fluorescence: maximal fluorescence $\left(\mathrm{F}_{\mathrm{V}}: \mathrm{F}_{\mathrm{M}}\right)$ ratio in the aquatic plants. This ratio is commonly used as an index of plant stress (Willits and Peet 2001). Only those with scores of at least 0.7 were deemed healthy and included in the experiment (Dan et al. 2000).

Zebra mussels, killer shrimp and bloody-red mysid were randomly selected from the tank to prevent bias towards particular sizes. Only those swimming normally (killer shrimp, bloody-red mysid) or siphoning water and responding to stimuli (zebra mussels) were used in the experiment (Beyer et al. 2010). Zebra mussels ranged in total length from 8.0 to $22.0 \mathrm{~mm}$ (median $16.0 \mathrm{~mm}$ ), killer shrimp ranged from 8.7 to $20.9 \mathrm{~mm}$ (median $11.2 \mathrm{~mm}$ ) and bloody-red mysid ranged from 10.5 to $13.8 \mathrm{~mm}$ (median $12.5 \mathrm{~mm}$ ). There was no significant difference in the sizes of zebra mussels (Kruskal-Wallis, $\mathrm{H}=2.1, d f=3, p=0.55$ ), killer shrimp $(\mathrm{H}=3.17, d f=3, p=0.36)$ or bloodyred mysid $(\mathrm{H}=7.39, d f=3, p=0.06)$ assigned to different treatments.

To mimic the conditions of an angler's keep net, each animal or plant fragment $(n=240$ per species) was placed in a bag $(50 \mathrm{~mm} \times 50 \mathrm{~mm})$ constructed from the mesh (2 $\mathrm{mm}$ spacing) of a typical polyester coarse angling keep net (Keepnets Direct, UK). The bags were sealed with staples and submerged in dechlorinated tap water at $14 \pm 1{ }^{\circ} \mathrm{C}$ for $1 \mathrm{~h}$ to simulate an angling trip. Once damp, the nets were subjected to one of three treatments: (1) hot water 
$\left(45^{\circ} \mathrm{C}\right)$; (2) hot water $\left(45^{\circ} \mathrm{C}\right)$ and drying, and (3) drying only; or a no-treatment control (see Table 1). For the hot water treatments, a 15 min exposure period was selected as this duration has been previously shown to be effective at causing $100 \%$ mortality in killer shrimp (Stebbing et al. 2011) and because this is the maximum period of time that a treatment could realistically be applied in the field. For the drying treatments, net bags were laid on plastic trays in a temperature controlled room $\left(14 \pm 1{ }^{\circ} \mathrm{C}\right.$, light: dark cycle $12: 12 \mathrm{~h}$, gently circulating air $1.23 \mathrm{~m} / \mathrm{s})$. In the control, net bags were placed in thin, transparent unsealed plastic bags to hinder drying and stored in the same way as the drying treatments. The relative rates at which the net bags dried in each treatment are supplied as supplementary material.

Animals/plants were observed and recorded as alive/dead at six time points after the initial treatment: $1 \mathrm{~h}, 1,2,4,8$, and 16 days. Our previous research indicated that $86 \%$ of anglers use their equipment at least once a fortnight (Anderson et al. 2014) so the time units were chosen to represent time intervals during which angling equipment might be stored for between uses. Because the plants and animals had to be handled and/or exposed to water to test for survival, separate batches of 10 animals were tested at each time point. Having been tested, individuals were not returned to the experiment.

\section{Testing survival}

Zebra mussels were assumed dead if their shells gaped and they did not respond to stimuli either immediately after the experiment or after $1 \mathrm{~h}$ recovery in a container of dechlorinated water at $14 \pm 1{ }^{\circ} \mathrm{C}$ (Ricciardi et al. 1995; Beyer et al. 2010; Comeau et al. 2011). Killer shrimp and bloody-red mysid were considered dead if they were discoloured (or had begun to decompose) and neither responded to stimuli nor swam after being put in a container of dechlorinated water for $1 \mathrm{~h}$. For the plants, a FluorPen was used at the end of the experiments to measure the variable to maximal fluorescence of leaves $\left(\mathrm{F}_{\mathrm{v}}: \mathrm{F}_{\mathrm{m}}\right)$. This measurement is widely used as an indication of plant stress (Willits and Peet 2001), and plants with

Table 1 Summary of experimental set up

\begin{tabular}{|c|c|c|c|c|c|c|c|}
\hline \multirow[t]{2}{*}{ Treatment } & \multirow[t]{2}{*}{ Description } & \multicolumn{6}{|c|}{ Number of individuals checked at each time point } \\
\hline & & $1 \mathrm{~h}$ & 1 day & 2 days & 4 days & 8 days & 16 days \\
\hline Hot water only & $\begin{array}{l}60 \times \text { individual mesh nets submerged } \\
\text { in a waterbath at } 45^{\circ} \mathrm{C} \text { for } 15 \text { min in } \\
\text { a randomly assigned order. } \\
\text { Immediately afterwards, nets put } \\
\text { inside individual (unsealed) plastic } \\
\text { bags and stored on a tray in climate } \\
\text { controlled room at } 14 \pm 1{ }^{\circ} \mathrm{C}\end{array}$ & 10 & 10 & 10 & 10 & 10 & 10 \\
\hline Hot water and drying & $\begin{array}{l}60 \text { individual mesh nets submerged in } \\
\text { water bath at } 45^{\circ} \mathrm{C} \text { for } 15 \text { min in a } \\
\text { randomly assigned order. } \\
\text { Immediately afterwards, nets laid } \\
\text { out on tray in climate controlled } \\
\text { room at } 14 \pm 1{ }^{\circ} \mathrm{C}\end{array}$ & 10 & 10 & 10 & 10 & 10 & 10 \\
\hline Drying only & $\begin{array}{l}60 \text { mesh nets laid out on trays in } \\
\text { climate controlled room at } \\
14 \pm 1^{\circ} \mathrm{C}\end{array}$ & 10 & 10 & 10 & 10 & 10 & 10 \\
\hline Control & $\begin{array}{l}60 \text { mesh nets put inside individual } \\
\text { (unsealed) plastic bags and stored on } \\
\text { a tray in climate controlled room at } \\
14 \pm 1{ }^{\circ} \mathrm{C}\end{array}$ & 10 & 10 & 10 & 10 & 10 & 10 \\
\hline
\end{tabular}

The description outlines the treatment that each polyester net (containing an individual animal or plant fragment, $\mathrm{n}=240$ per species) was exposed to after having been submerged in dechlorinated water at an ambient temperature for $1 \mathrm{~h}$ to simulate the minimum length of an angling trip 
$F_{\mathrm{v}}: \mathrm{F}_{\mathrm{m}}$ values of 0.3 or below were considered to be dead (Dan et al. 2000).

\section{Crayfish experiment}

At the beginning of the experiment a single animal was removed from the holding tank, sexed, measured from the tip of the rostrum to the end of the cephalothorax (mm) and placed into a water bath at $30,40,50$ or $60{ }^{\circ} \mathrm{C}$ $\left( \pm 1{ }^{\circ} \mathrm{C}\right.$ ) for either $5,1 \mathrm{~min}$ or $5 \mathrm{~s}$ for one of the temperatures (five animals per treatment $\times$ nine treatments). Where all individuals survived a treatment after $5 \mathrm{~min}$, or $1 \mathrm{~min}$, the treatment was not repeated for the shorter time period(s). Once the animal had been submerged for the required duration, it was removed and placed into dechlorinated water at $14 \pm 1{ }^{\circ} \mathrm{C}$ for a recovery period of $30 \mathrm{~min}$. Behavioural observations to determine mortality were made one and 30 min into the recovery period. Animals were considered dead if they would not right themselves if placed on their back and were not responsive to stimuli. No animal was used more than once. The carapace length of animals used ranged from 30 to $70 \mathrm{~mm}$ (median $45 \mathrm{~mm}$ ) with no significant difference between treatments (KruskalWallis $\mathrm{H}=5.52, d f=8, p=0.70$ ).

\section{Data analysis}

Generalised linear models (GLMs) with binomial errors were used to identify whether species or treatment were significant predictors of survival (proportion alive) at each time point ( $1 \mathrm{~h}, 1,2,4,8,16)$. To test the relative effectiveness of two different treatments at a particular time point, paired $\chi^{2}$ tests (R package: prop. test) were used to compare differences in the proportion of individuals alive. Dose response curves were plotted to illustrate changes in mortality over time and to estimate $\mathrm{LT}_{50}$ and $\mathrm{LT}_{90}$ for the treatments which did not cause $100 \%$ mortality. All statistical analysis were carried out using 'R' (R Development Core Team 2012).

\section{Results}

\section{Check Clean Dry experiment}

Mortality differed between treatments and increased over time for all treatments. The hot water treatment and hot water and drying treatment resulted in 99 and $97 \%$ mortality within $1 \mathrm{~h}$, respectively, whereas it took 7.52 days to reach $\mathrm{LT}_{90}$ with the drying treatment and a projected 17.16 days to reach $\mathrm{LT}_{90}$ for the control group (Fig. 1, Table 2).

More specifically, the hot water treatment resulted in $100 \%$ mortality in six of the seven species and $90 \%$ mortality in the seventh species (New Zealand pigmyweed) within $1 \mathrm{~h}$, regardless of whether the nets were exposed to the air (hot water and dry treatment) or immediately put into a bag (hot water only treatment) afterwards. The hot water and dry treatment showed similar results, with $100 \%$ mortality across 6 of the 7 species and $80 \%$ mortality in New Zealand pigmyweed after $1 \mathrm{~h}$. A much longer time period was required for the drying treatment to cause mortality, with $19 \%$ of individuals subjected to the drying treatment still alive after 8 days and $10 \%$ still alive after 16 days. In the control group, mortality was low with $70 \%$ of individuals alive after 7 days and $30 \%$ still alive after the full 16 days, among all species except bloody-red mysid. Bloody-red mysid showed high mortality (100\% within 1 day across all treatments except drying (Fig. 1).

Treatment was a significant predictor of mortality after $1 \mathrm{~h} \quad(\mathrm{GLM}, \quad$ Estimate $=1.28, \quad \mathrm{SE}=0.15$, $\mathrm{Z}=8.4, p<0.001), 1$ day (GLM, Estimate $=2.36$, $\mathrm{SE}=0.26, \quad \mathrm{Z}=9.02, \quad p<0.001), \quad 8$ days (Estimate $=0.698, \mathrm{SE}=0.14, \mathrm{Z}=4.75, \quad p<0.001$ ), and 16 days $\quad($ Estimate $=0.624, \quad \mathrm{SE}=0.17$, $\mathrm{Z}=3.59, p<0.001$ ), (Fig. 1). Species was not a significant predictor of mortality at any of the four time points (binomial GLM, $p>0.05$ ).

There were no significant differences in survivorship between the hot water and dry treatment and hot water only treatment at any of the time points, indicating that drying equipment after submersion in hot water has no additional benefit (Table 3). The hot water only treatment killed a significantly higher proportion of individuals than the drying treatment or control at every time point (Table 3, Fig. 1).

Although hot water is clearly the most effective treatment, it may not always be available to recreational water users. Drying, despite not being as effective at causing mortality as hot water (Fig. 1), caused significantly higher mortality than the control from day $4\left(\chi^{2}=8.49, p<0.01\right)$ onwards (Table 3 ), at which point the nets had dried out completely (Supplementary material Figure S1) Over half of 

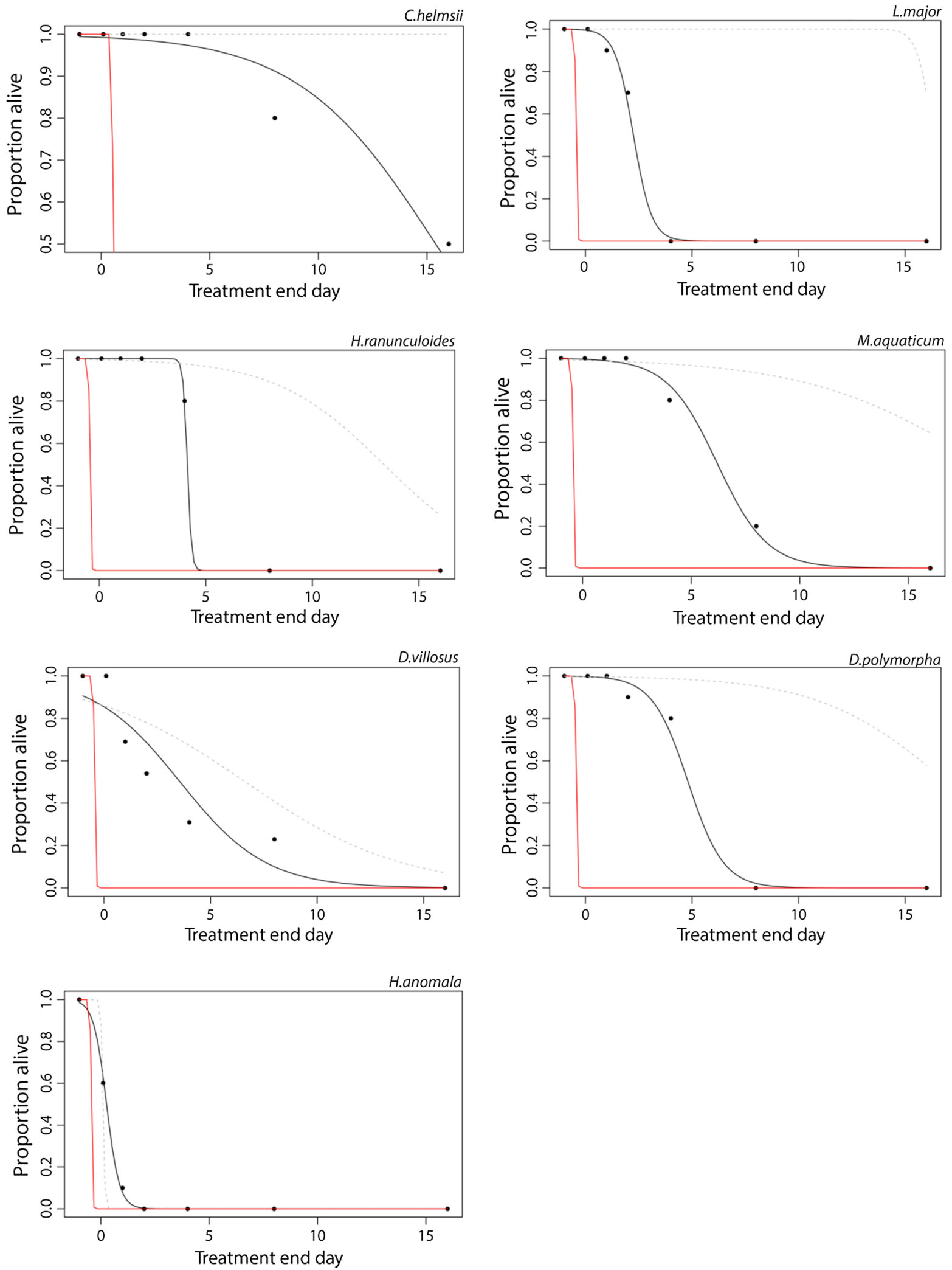
४Fig. 1 Dose response curves showing projected survival over time for hot water only (red line), drying (black line and data points) and control (dashed line) treatments. The solid line shows projected survival for the drying treatment. The dashed line shows projected survival for the control treatment and the red line shows projected survival for the clean treatment

species exposed to the drying treatment reached LT90 in 1 week (7.52 days), while aquatic plants such as curly water thyme and floating pennywort survived only 3-4 days under the drying treatment (Table 2). In contrast, New Zealand pigmyweed could survive over 23 days of drying (Table 2). Overall, drying took significantly less time to cause $50 \%$ mortality (Independent samples $\mathrm{T}$ test: $\mathrm{t}=-2.76, \quad d f=10$, $p<0.05)$ and $90 \%$ mortality $(\mathrm{t}=-2.89, d f=10$, $p<0.05)$ compared to the control treatment.
Crayfish pilot experiment

No mortalities were observed when signal crayfish were exposed to either $50{ }^{\circ} \mathrm{C}$ or $60{ }^{\circ} \mathrm{C}$ for $5 \mathrm{~s}$ (Table 4). With exposure to $50{ }^{\circ} \mathrm{C}$ for $5 \mathrm{~s}$ chronic behaviour was observed with animals inactive and unable to right themselves, however, all animals appeared to recover fully after $30 \mathrm{~min}$. With exposure to $5 \mathrm{~s}$ at $60{ }^{\circ} \mathrm{C}$, chronic effects were also observed and behaviour deteriorated during the recovery period.

With $1 \mathrm{~min}$ of exposure, mortalities were observed at $60{ }^{\circ} \mathrm{C}$ (30 min after exposure). With $75 \%$ mortalities observed at $50{ }^{\circ} \mathrm{C}$, but recovery being observed during the recovery period when exposed to $40{ }^{\circ} \mathrm{C}$.

With $5 \mathrm{~min}$ of exposure, mortalities where observed in all animals exposed to 60,50 and $40{ }^{\circ} \mathrm{C}$ and recovery observed at $30{ }^{\circ} \mathrm{C}$ post exposure.

Table 2 Mean number of days taken for each species to reach $50 \%$ mortality $\left(\mathrm{LT}_{50}\right)$ and $90 \%$ mortality $\left(\mathrm{LT}_{90}\right)$ in the control and drying treatments

\begin{tabular}{lllll}
\hline Species & LT 50 (days) & & \multicolumn{2}{c}{ LT 90 (days) } \\
\cline { 2 - 3 } & Drying treatment & Control & Drying treatment & Control \\
\hline C.helmsii & 15.42 & $>100^{\mathrm{a}}$ & 22.53 & $190^{\mathrm{a}}$ \\
H.ranunculoides & 4.13 & 13.35 & 4.34 & 17.14 \\
L.major & 2.25 & 16.31 & 3.21 & 27.65 \\
M.aquaticum & 6.19 & 18.52 & 8.73 & 0.10 \\
H.anomala & 0.15 & 0.10 & 0.95 & 23.46 \\
D.polymorpha & 4.81 & 16.93 & 6.62 & 15.59 \\
D.villosus & 3.43 & 6.45 & 8.54 & $17.16^{\mathrm{a}}$ \\
MEAN & 6.93 & $11.94^{\mathrm{a}}$ & 7.52 & \\
\hline
\end{tabular}

Results were calculated from dose-response curves

a As none of the $C$. helmsii died during in the control experiment, it was not possible to accurately calculate its projected survival under the control treatment. The species from was therefore excluded the mean calculation and tests

Table 3 Results of paired $X^{2}$ tests to compare the level of mortality (proportion) between treatments after $1 \mathrm{~h}, 1,8$ and 16 days

\begin{tabular}{|c|c|c|c|c|}
\hline Treatment comparison & $1 \mathrm{~h}$ & 1 day & 8 days & 16 days \\
\hline Clean (hot water) only versus clean (hot water) and dry & NA & 2.31 & NA & NA \\
\hline Clean (hot water) only versus dry only & $117.24 * * *$ & $95.68 * * *$ & $12.16 * * *$ & $7.58 * *$ \\
\hline Clean (hot water) only versus control & $113.77 * * *$ & $101.37 * * *$ & $70.77 * * *$ & $43.44 * * *$ \\
\hline Dry only versus control & NA & 0.05 & $34.34 * * *$ & $25.20 * * *$ \\
\hline Clean (hot water) and dry versus control & $110.03 * * *$ & $86.96 * * *$ & $70.77 * * *$ & $43.44 * * *$ \\
\hline
\end{tabular}

Figures show $\chi^{2}$ value

$\mathrm{NA}=$ result was the same for both treatments so $\chi^{2}$ tests could not be performed

$* p<0.05, * * p<0.01, * * * p<0.001$ 
Table 4 Results of the percentage mortalities observed in the heat exposure experiment with crayfish

\begin{tabular}{|c|c|c|c|c|c|c|}
\hline \multirow{2}{*}{$\begin{array}{l}\text { Exposure } \\
\text { Recovery }\end{array}$} & \multicolumn{2}{|c|}{$5 \min (n=20)$} & \multicolumn{2}{|c|}{$1 \min (n=15)$} & \multicolumn{2}{|c|}{$5 \mathrm{~s}(\mathrm{n}=10)$} \\
\hline & $1 \mathrm{~m}$ & $30 \mathrm{~m}$ & $1 \mathrm{~m}$ & $30 \mathrm{~m}$ & $1 \mathrm{~m}$ & $30 \mathrm{~m}$ \\
\hline $60^{\circ} \mathrm{C}$ & 100 & 100 & 65 & 100 & 0 & 0 \\
\hline $50{ }^{\circ} \mathrm{C}$ & 100 & 100 & 75 & 75 & 0 & 0 \\
\hline $40^{\circ} \mathrm{C}$ & 100 & 100 & 0 & 0 & & \\
\hline $30^{\circ} \mathrm{C}$ & 0 & 0 & & & & \\
\hline
\end{tabular}

Figures expressed as percentage of crayfish in each treatment group. Recovery was measured 1 and $30 \mathrm{~min}$ after treatment ended for each temperature

\section{Discussion}

Hot water $\left(45^{\circ} \mathrm{C}\right)$ caused $99 \%$ mortality across the seven aquatic INNS used in the primary experiment within $1 \mathrm{~h}$ of treatment. These results demonstrate that submerging water sports equipment in $45^{\circ} \mathrm{C}$ water for $15 \mathrm{~min}$ is an extremely effective method for killing a range of invasive non-native animals and plants in a short time frame. Moreover, hot water was effective regardless of whether or not the net which the invader was in was subsequently dried, or remained damp. New Zealand pigmyweed and parrot's feather, were the only two species to survive submersion in hot water after $1 \mathrm{~h}$, although all individuals were dead 1 day after treatment. Particular caution should be taken when using recreational equipment in areas where these plants are known to be present.

The results of our hot water experiment were similar to those of previous studies which reported $100 \%$ mortality in zebra mussels and quagga mussels (D. rostriformis bugensis) in $5 \mathrm{~min}$ at $43{ }^{\circ} \mathrm{C}$; adult spiny waterfleas (B. longimanus) in $10 \mathrm{~min}$ at $43{ }^{\circ} \mathrm{C}$ (Beyer et al. 2010); and spiny water flea eggs at $50{ }^{\circ} \mathrm{C}$ for $\geq 10 \mathrm{~min}$ (Branstrator et al. 2013). Although some of these INNS reached $100 \%$ mortality in cooler temperatures or a shorter time period, we believe it is important to recommend a consistent treatment which is effective against a wide range of species, without the need for waterusers to know which INNS are present. As $45{ }^{\circ} \mathrm{C}$ for $15 \mathrm{~min}$ was identified as the most efficient time/temperature combination to cause $100 \%$ mortality in killer shrimp (Stebbing et al. 2011), we recommend that this longer time period is used as a consistent treatment.
Adult crayfish are unlikely to remain attached to equipment without being noticed, but were used in this study as a proxy for juvenile crayfish. Although $100 \%$ mortalities were observed when crayfish were exposed to $60{ }^{\circ} \mathrm{C}$ for $1 \mathrm{~min}$, this water temperature could degrade watersports equipment and has the potential to cause burns in children (Feldman et al. 1998). With $100 \%$ mortality observed with $5 \mathrm{~min}$ exposure at $40{ }^{\circ} \mathrm{C}$, the recommendation of exposing water sport equipment in $45^{\circ} \mathrm{C}$ water for $15 \mathrm{~min}$ is considered more than sufficient to cause mortality in juvenile crayfish.

In the absence of hot water, drying was still found to be a significantly more effective treatment than doing nothing (control) and caused $90 \%$ mortality in a mean of 7.52 days in all species except New Zealand pigmyweed, suggesting that it would be suitable as a biosecurity treatment for anglers who go fishing once a fortnight or less frequently in areas where New Zealand pigmyweed is not present. Our desiccation treatment took longer to cause mortality in plants than previous studies. For example, drying Eurasian water milfoil (Myriophyllum spicatum), resulted in $71 \%$ mortality within $1 \mathrm{~h}$ and $100 \%$ mortality within 1 day (Jerde et al. 2012). In an animal experiment, air exposure of $\geq 6 \mathrm{~h}$ prevented the dormant egg stages of spiny waterflea from hatching (Branstrator et al. 2013). In contrast, the plants in our study took at least of 2.25 days to reach $\mathrm{LT}_{50}$ and 3.21 to reach $\mathrm{LT}_{9}$ and the animals took at least $22 \mathrm{~h}$ to reach $\mathrm{LT}_{90}$ (Table 2). The longer time-to-mortality in our desiccation treatment is likely to be due to the plant fragments and animals remaining enclosed in damp nets which retained water for a number of days after initial submersion (Figure S1, supplementary material) whereas the plants/animals were not enclosed in the aforementioned studies. Our results demonstrate that drying can take many days, particularly for INNS entrapped in large equipment and in cool or damp conditions and is a more subjective biosecurity treatment (i.e. people's perceptions of what 'dry' is may vary). These results support previous studies which show that complete desiccation is required for it to be effective (Jerde et al. 2012; Poznanska et al. 2013), making it an unsuitable decontamination method for use by anglers who go fishing frequently.

Despite some mortality, six of the seven species (all except bloody-red mysid) in the control group were able to survive for at least 16 days in damp conditions. As recent research suggests that $64 \%$ of anglers visit 
multiple catchments within a fortnight (Anderson et al. 2014), this demonstrates the potential for invaders to survive in damp equipment in the absence of biosecurity. Several of the species in this experiment were not previously thought to be able to survive for this long out of water: killer shrimp has only been reported to survive for 15 days out of water (Fielding 2011) and zebra mussels for 3-5 days (Ricciardi et al. 1995). Our results also demonstrate that aquatic plants including floating pennywort and parrot's feather can survive out of water for at least 16 days which, to the best of our knowledge, has not been previously reported. Unlike the other species tested, bloody-red mysid showed high mortality (100\% within 1 day in all treatments except drying). This species appeared particularly fragile, so it is probable that handling in the laboratory or physical damage by the nets resulted in mortality. Based on our results, it seems unlikely that bloody-red mysid would survive transport in an angling net, therefore water-based transfer methods (such as the ballast water of boats) may be more important vectors for this species; as presumed for its introduction into the Great Lakes (Brooking et al. 2010).

Hot water provides a rapid and easy method to clean equipment as part of the Check Clean Dry protocol and we believe it is a simple and effective method to recommend to the anglers (e.g. $78 \%$ of those in the UK) who do not currently clean their kit after use (Anderson et al. 2014). While we have demonstrated the effectiveness of this method at killing a range of INNS, we stress that further research must be conducted to test the effectiveness of hot water as a treatment to kill aquatic pathogens, such as Gyrodactlylus salaris, a salmon ectoparasite which is considered to be the most important exotic fish-disease threat to the UK (Peeler et al. 2004); Aphanomyces astaci, the causal agent of crayfish plague (Oidtmann et al. 2002) and Batrachochytrium dendrobatidis, the causal agent of chytrid disease in amphibians (Johnson and Speare 2003). We acknowledge that aquatic parasites such as these pose a similar economic and ecological risk to INNS and that anglers using equipment in multiple countries pose a risk of parasite dispersal (Anderson et al. 2014). We advocate the continued use of Virkon Aquatic $^{\circledR}$ (DuPont 2014) as a biosecurity agent for anglers travelling between countries or using equipment in areas where aquatic parasites may be present. Further work into the effectiveness of hot water as a control measure for parasites would be of significant use in demonstrating hot water as a single 'catch all' biosecurity message for both invasive species and aquatic pathogens.

\section{Conclusion}

Hot water fulfils the criteria for an effective biosecurity treatment. Not only does it cause $99 \%$ mortality within an hour, it is environmentally sound and cost effective (O’Neill and MacNeill 1991; Beyer et al. 2010; Stebbing et al. 2011; Perepelizin and Boltovskoy 2011) and the recommended temperature of $45^{\circ} \mathrm{C}$, is below the temperature at which hot water is thought to be able to cause burns in children $\left(52{ }^{\circ} \mathrm{C}\right)$ making it safe to use by children as well as adults (Feldman et al. 1998). However, we recommend that water is disposed of on land and away from a water source.

These results provided evidence that hot water is effective at killing a range of high impact invasive species in a short time frame. The use of hot water ( $45^{\circ} \mathrm{C}$ for $15 \mathrm{~min}$ ) for the 'Clean' stage of the UKs national Check Clean Dry biosecurity awareness campaign would greatly enhance biosecurity efforts. In addition to anglers, this method could be used by water sports participants with wetsuits or equipment that can easily be submerged, as well as ecologists, environmental scientists and field centre staff and volunteers who use nets, waders and other equipment to undertake freshwater fieldwork in the UK.

Acknowledgments The authors would like to thank Ellis Bradbury, Hannah Lintott, Ammar Kahla and Georgina Rimmer for technical assistance with this research and two anonymous reviewers for helpful comments on the manuscript. The research was jointly funded by grants from the Department of Environment, Food and Rural Affairs (Defra), Natural Environment Research Council (NERC), and a $\mathrm{PhD}$ case studentship funded by Biotechnology \& Biological Sciences Research Council (BBSRC) and the Centre for Environment, Fisheries and Aquaculture Science (Cefas), awarded to LGA.

Open Access This article is distributed under the terms of the Creative Commons Attribution License which permits any use, distribution, and reproduction in any medium, provided the original author(s) and the source are credited.

\section{References}

Anderson LG, White PCL, Stebbing PD et al (2014) Biosecurity and vector behaviour: evaluating the potential threat posed 
by anglers and canoeists as pathways for the spread of invasive non-native species and pathogens. PLoS One 9:e92788. doi:10.1371/journal.pone.0092788

Bacela-Spychalska K, Grabowski M, Rewicz T et al (2013) The "killer shrimp" Dikerogammarus villosus (Crustacea, Amphipoda) invading Alpine lakes: Overland transport by recreational boats and scuba-diving gear as potential entry vectors? Aquat Conserv Mar Freshw Ecosyst 23:606-618. doi:10.1002/aqc. 2329

Beyer J, Moy P, Stasio B (2010) Acute upper thermal limits of three aquatic invasive invertebrates: hot water treatment to prevent upstream transport of invasive species. Environ Manage 47:67-76. doi:10.1007/s00267-010-9573-4

Bothwell ML, Lynch DR, Wright H, Deniseger J (2009) On the boots of fishermen: the history of didymo blooms on Vancouver Island, British Columbia. Fisheries 34:382-388

Branstrator DK, Shannon LJ, Brown ME, Kitson MT (2013) Effects of chemical and physical conditions on hatching success of Bythotrephes longimanus resting eggs. Limnol Oceanogr 58:2171-2184. doi:10.4319/lo.2013.58.6.2171

Briski E, Wiley CJ, Bailey SA (2012) Role of domestic shipping in the introduction or secondary spread of nonindigenous species: biological invasions within the Laurentian Great Lakes. J Appl Ecol 49:1124-1130. doi:10.1111/j.13652664.2012.02186.x

Broads Authority (2013) Take action to stop the spread of invasive species in the Broads. http://www.broads-authority. gov.uk/_data/assets/pdf_file/0019/405325/Check-cleandry-leaflet.pdf

Brooking TE, Rudstam LG, Krueger SD et al (2010) First occurrence of the mysid Hemimysis anomala in an inland lake in North America, Oneida Lake, NY. J Great Lakes Res 36:577-581. doi:10.1016/j.jglr.2010.04.004

Buchan LAJ, Padilla DK (1999) Estimating the probability of long-distance overland dispersal of invading aquatic species. Ecol Appl 9:254-265

Caplat P, Coutts SR (2011) Integrating ecological knowledge, public perception and urgency of action into invasive species management. Environ Manage 48:878-881. doi:10.1007/s00267-011-9747-8

Comeau S, Rainville S, Baldwin W et al (2011) Susceptibility of quagga mussels (Dreissena rostriformis bugensis) to hot-water sprays as a means of watercraft decontamination. Biofouling 27:267-274. doi:10.1080/08927014.2011.564275

Dan TV, Sankaran K, Saxena PK (2000) Metal tolerance of scented geranium (Pelargonium Sp. "Frensham"): effects of cadmium and nickel on chlorophyll fluorescence kinetics. Int J Phytoremediation 2:91-104. doi:10.1080/ 15226510008500032

Development Core Team R (2012) R: A language and environment for statistical computing. R Foundation for Statistical Computing, Vienna

Dudgeon D, Arthington AH, Gessner MO et al (2006) Freshwater biodiversity: importance, threats, status and conservation challenges. Biol Rev 81:163. doi:10.1017/ S1464793105006950

DuPont (2014) Virkon ${ }^{\circledR}$ aquatic efficacy against specific fish pathogens. http://www2.dupont.com/DAHS_EMEA/en_ GB/ahb/fish/efficacy_data.html

Environment Agency (2011) Biodiversity's most wanted. http:// www.environment-agency.gov.uk/news/132112.aspx
Feldman KW, Schaller RT, Feldman JA, McMillon M (1998) Tap water scald burns in children. Inj Prev 4:238-242

Fielding N (2011) Dikerogammarus villosus: preliminary trials on resistance to control measures. Freshw Biol Assoc Newsl 54:16-17

Gallardo B, Aldridge DC (2013) The "dirty dozen": socio-economic factors amplify the invasion potential of 12 highrisk aquatic invasive species in Great Britain and Ireland. J Appl Ecol. doi:10.1111/1365-2664.12079

Gates KK, Guy CS, Zale AV, Horton TB (2008) Adherence of Myxobolus cerebralis Myxospores to Waders: implications for disease dissemination. N Am J Fish Manag 28:1453-1458. doi:10.1577/M08-025.1

Holdich DM (2001) Biology of freshwater crayfish. Ames, Iowa, Wiley

Jerde C, Barnes M, DeBuysser E et al (2012) Eurasian watermilfoil fitness loss and invasion potential following desiccation during simulated overland transport. Aquat Invasions 7:135-142. doi:10.3391/ai.2012.7.1.015

Johnson ML, Speare R (2003) Survival of Batrachochytrium dendrobatidis in water: quarantine and disease control implications. Emerg Infect Dis 9:922

Johnson LE, Ricciardi A, Carlton JT (2001) Overland dispersal of aquatic invasive species: a risk assessment of transient recreational boating. Ecol Appl 11:1789-1799

Kilian JV, Klauda RJ, Widman S et al (2012) An assessment of a bait industry and angler behaviour as a vector of invasive species. Biol Invasions. doi:10.1007/s10530-012-0173-5

Kilroy C, Lagerstedt A, Davey A, Robinson K (2006) Studies on the survivability of the invasive diatom Didymosphenia geminata under a range of environmental and chemical conditions. Report by National Institute of Water \& Atmospheric Research, New Zealand

Kolar CS, Lodge DM (2001) Progress in invasion biology: predicting invaders. Trends Ecol Evol 16:199-204

Ludwig HR, Leitch JA (1996) Interbasin transfer of aquatic biota via anglers' bait buckets. Fisheries 21:14-18. doi:10. 1577/1548-8446(1996)021<0014:ITOABV>2.0.CO;2

Mack R, Simberloff D, Lonsdale WM et al (2000) Biotic invasions: causes, epidemiology, global consequences, and control. Ecol Appl 10:689-710

O’Neill CR, MacNeill DB (1991) The zebra mussel (Dreissena polymorpha): an unwelcome North American invader. Sea Grant Coastal Resources Factsheet, Brockport

Oidtmann B, Heitz E, Rogers D, Hoffmann RW (2002) Transmission of crayfish plague. Dis Aquat Organ 52: 159-167

Oreska MPJ, Aldridge DC (2010) Estimating the financial costs of freshwater invasive species in Great Britain: a standardized approach to invasive species costing. Biol Invasions 13:305-319. doi:10.1007/s10530-010-9807-7

Peeler EJ, Gardiner R, Thrush MA (2004) Qualitative risk assessment of routes of transmission of the exotic fish parasite Gyrodactylus salaris between river catchments in England and Wales. Prev Vet Med 64:175-189. doi:10. 1016/j.prevetmed.2004.05.005

Perepelizin PV, Boltovskoy D (2011) Hot water treatment (chronic upper lethal temperature) mitigates biofouling by the invasive asian mussel Limnoperna fortunei in industrial installations. Environ Sci Technol 45:7868-7873. doi:10. 1021/es2014852 
Poznanska M, Kakareko T, Krzyzynski M, Kobak J (2013) Effect of substratum drying on the survival and migrations of PontoCaspian and native gammarids (Crustacea: Amphipoda). Hydrobiologia 700:47-59. doi:10.1007/s10750-012-1218-6

Ricciardi A, Serrouya R, Whoriskey FG (1995) Aerial exposure tolerance off zebra and quagga mussels (Bivalvia: Dreissenidae): implications for overland dispersal. Can J Fish Aquat Sci 52:470-477

Stasko AD, Patenaude AL, Strecker AL, Arnott SE (2012) Portage connectivity does not predict establishment success of canoe-mediated dispersal for crustacean zooplankton. Aquat Ecol 49:9-24

Stebbing P, Sebire M, Lyons B (2011) Evaluation of a number of treatments to be used as biosecurity measures in controlling the spread of the invasive killer shrimp (Dikerogammarus villosus). Report C5256, Centre for Environment, Fisheries and Aquaculture Science

Strayer DL (2010) Alien species in fresh waters: ecological effects, interactions with other stressors, and prospects for the future. Freshw Biol 55:152-174. doi:10.1111/j.13652427.2009.02380.x

Vander Zanden MJ, Hansen GJA, Higgins SN, Kornis MS (2010) A pound of prevention, plus a pound of cure: early detection and eradication of invasive species in the Laurentian Great Lakes. J Great Lakes Res 36:199-205. doi:10.1016/j.jglr.2009.11.002

Willits DH, Peet MM (2001) Measurement of chlorophyll fluorescence as a heat stress indicator in tomato: laboratory and greenhouse comparisons. J Am Soc Hortic Sci 126:188-194 